Tatjana Z. Mihajlov DOI: 10.19090/zop.2016.25.131-144

Ministarstvo prosvete, nauke i

UDC: 371.121:001.818

tehnološkog razvoja, Stručni rad

Školska uprava Zrenjanin

Milica J. Andevski

Univerzitet u Novom Sadu,

Filozofski fakultet

\title{
ANALIZA STAVOVA PEDAGOGA PREMA SPOLJAŠNJEM VREDNOVANJU ${ }^{1}$
}

Apstrakt: Cilj sprovedenog istraživanja je ispitivanje kako sručni saradnici (pedagozi) procenjuju doprinos spoljašnjeg vrednovanja i da li uočavaju njegov značaj za unapređenje rada i lični i profesionalni razvoj. Podaci su prikupljeni tehnikom anketiranja, a kao instrumenti korišćeni su anketni upitnik i skala procene. Uzorak je činilo osam stručnih saradnika iz osam škola koje su prošle spoljašnje vrednovanje. Dobijeni rezultati ukazuju da stručni saradnici procenjuju spoljašnje vrednovanje rada škola kao važan doprinos, ali pokazuju i razlike u pogledu tih shvatanja i otvaraju mogućnost nastavka istraživanja uzroka ovakvih shvatanja nastavnika.

Ključne reči: stručni saradnici, stavovi, spoljašnje vrednovanje.

\section{Uvod}

Potreba za spoljašnjim vrednovanjem nastala je iz svesti o potrebi stalnog unapređivanja obrazovno-vaspitnog procesa, praćenja i sagledavanja jasne slike o školi. Upravo tome je posvećen i poseban član Zakona koji odnosi na osiguranje kvaliteta rada ustanove (Član 48 Zakona o osnovama sistema obrazovanja i vaspitanja). Prema ovom Zakonu, vrednovanje kvaliteta rada ustanova podrazumeva dva njegova oblika i predstavlja procenu kvaliteta delovanja. Vrši se na dva načina: samovrednovanjem i spoljašnjim vrednovanjem. Samovrednovanje je

${ }^{1}$ Ovaj rad je nastao kao deo istraživanja u okviru doktorskih studija Metodika nastave na Filozofskom fakultetu u Novom Sadu na predmetu Doktorska disertacija-istraživanje na temi, pod mentorstvom prof.dr Milice Andevski.

Tatjana Mihajlov, mihajlov.tatjana@gmail.com, Milica Andevski, andevski@ff.uns.ac.rs 
interni nadzor, postupak koji vodi jačanju škole i unapređivanju kvaliteta „iznutra“. Spoljašnje vrednovanje je vrsta kompleksnog eksternog nadzora, sastavni deo sistema vrednovanja kvaliteta obrazovno-vaspitnog procesa a koji se vrši u okviru definisanih oblika kvaliteta; bazirano je na standardima, indikatorima i normama, kao i na dokazima koji su validni, autentični, pouzdani i konzistentni.

Sistem vrednovanjakoji podrazumevasamovrednovanjeispoljašnje vrednovanje doprinosi unapređivanju kvaliteta rada škole jer obuhvata vrednovanje svih vidova života i rada škole koji imaju uticaj na nastavu, učenje i rezultate učenja. U reformskom smislu, procesi vrednovanja kvaliteta prate trendove reformskih procesa u evropskim zemljama, gde je ovaj proces stavljen u centar pažnje jer se vrši u okviru definisanih oblasti kvaliteta u skladu sa donetim standardima. Samovrednovanje kvaliteta rada je procena kvaliteta rada koju sprovodi samostalno škola na osnovu standarda kvaliteta rada i na taj način sebe stavlja u aktivnu ulogu. Spoljašnje vrednovanje ukazuje na jake i slabe strane škole i na osnovu njih usmeravaju se akcije u područja gde je potrebno unaprediti kvalitet. $\mathrm{S}$ obzirom da je ovo proces koji je tek otpočeo kod nas, veoma je važno ispitati promene koje nastaju u tim područjima, potom kako ih učesnici obrazovno-vaspitnog procesa shvataju i procenjuju i da li samovrednovanje i spoljašnje vrednovanje doprinose kvalitetu rada škole.

Sistem vrednovanja koji podrazumeva spoljašnje vrednovanje doprinosi unapređivanju kvaliteta rada škole jer obuhvata vrednovanje svih vidova života i rada škole, a koji imaju uticaj na učenje i rezultate učenja.

Kao učesnici obrazovno-vaspitnog procesa, pedagozi su neizbežna karika u lancu sagledavanja kvaliteta rada škole, neizostavni su u sačinjavanju plana za unapređenje ostvarenih standarda škole, kao i za realizovanje neostvarenih standarda kvaliteta nakon sprovedenog spoljašnjeg vrednovanja, zbog čega je posebno važno ispitati sve promene koje nastaju u tim područjima, a posebno kako ih oni - kao učesnici obrazovno-vaspitnog procesa - procenjuju.

\section{Metodološki okvir istraživanja}

Predmet istraživanja je usmeren na analiziranje prakse spoljašnjeg vrednovanja, ispitivanje njegove primene i efekata koji proizilaze iz povratne informacije izveštaja spoljašnjeg vrednovanja i za cilj ima 
identifikovanje i analizu stavova učesnika obrazovno-vaspitnog procesa (nastavnika) i zadatak da ispita u kojoj meri stručni saradnici kao učesnici obrazovno-vaspitnog procesa procenjuju doprinos spoljašnjeg vrednovanja. Savremena obrazovna politika i reformski procesi posebnu pažnju poklanjaju standardima kvaliteta rada ustanova (škola) i obrazovanju usmerenom na postignuća (Zakon o osnovama sistema obrazovanja i vaspitanja, „Službeni glasnik RS“ br. 72/09, 52/11 i 55/02; Pravilnik o vrednovanju kvaliteta rada ustanove, „Službeni glasnik RS“ br. 9/12; Pravilnik o stručno-pedagoškom nadzoru, „Službeni glasnik RS““ br. 34/12). Podaci koji se dobijaju kroz procese spoljašnjeg vrednovanja (i samovrednovanja) omogućavaju redefinisanje Razvojnog plana škole, koji sadrži metode i postupke za ostvarivanje planiranih ciljeva škole i za praćenje i vrednovanje njegove realizacije. Na osnovu toga, problem istraživanja je definisan kroz pitanje: Da li je spoljašnje vredovanje škole uticalo na stručne saradnike (pedagoge) kao učesnike obrazovnovaspitnog procesa i doprinelo promenama u njihovim stavovima?

$\mathrm{U}$ istraživanju se pošlo od opšte hipoteze koja pretpostavlja da učesnici obrazovno-vaspitnog procesa, u ovom slučaju stručni saradnici pedagozi, procenjuju spoljašnje vredovanje kao važan činilac, te posebnih hipoteza da na njihove stavove ne utiču značajno razlike prema lokalitetu, vrsti škole i polu ispitanika. Korišćena je eksperimentalna metoda, expost facto postupak da bi se istražile efikasnosti promena nastalih nakon sprovedenog spoljašnjeg vrednovanja. Instrument istraživanja je skala procene Linkertovog tipa na pet nivoa koje je sastavio sam istraživač. Kod svake tvrdnje ispitanici su se, s obzirom na stepen saglašavanja, opredeljivali za jednu od ponuđenih mogućnosti koje su se kretale u rasponu 1-5: u potpunosti se slažem-5, uglavnom se slažem-4, delimično se slažem-3, veoma retko se slažem-2 i uopšte se ne slažem-1. Pri statističkoj obradi podataka korišćene su deskriptivne statističke mere za prikaz uzorka (frekvencije i procenti), za prikaz izraženosti merenih tvrdnji korišene su mere varijabilnosti: AS, SD, MIN i MAX. Za proveru pouzdanosti upitnika upotrbljen je Kronbahov alfa koeficijent, za prikaz značajnosti razlika Anova (F) i značajnost (p) i t test za nezavisne uzorke isto i značajnost (p), a za prikaz povezanosti (korelacija) Pirsonov koeficijent korelacije (r) i značajnost $(\mathrm{p})$.

Populaciju istraživanja činile su dve osnovne škole Severnobanatskog okruga i dve osnovne škole Srednjobanatskog okruga (u svakom po jedna seoska i jedna gradska škola, u kojima je izvršeno 
spoljašnje vrednovanje); dve srednje škole Severnobanatskog okruga i dve srednje škole Srednjobanatskog okruga; ukupno osam škola. Uzorak istraživanja je prigodnog tipa.

Tabela 1. Prikaz strukture uzorka

\begin{tabular}{|c|c|c|}
\hline & Broj ispitanika (SS) & Procenti $(\%)$ \\
\hline \multicolumn{3}{|l|}{ Pol } \\
\hline Muški & 0 & 0 \\
\hline Ženski & 8 & 100 \\
\hline Ukupno & 8 & 100 \\
\hline \multicolumn{3}{|c|}{ Mesto } \\
\hline Severnobanatski okrug & 4 & 50 \\
\hline Srednjobanatski okrug & 4 & 50 \\
\hline Ukupno & 8 & 100 \\
\hline \multicolumn{3}{|c|}{ Tip škole } \\
\hline Osnovna škola - grad & 2 & 25.00 \\
\hline Osnovna škola - selo & 2 & 25.00 \\
\hline Srednja stručna škola & 2 & 25.00 \\
\hline Gimnazija & 2 & 25.00 \\
\hline Ukupno & 8 & 100.00 \\
\hline
\end{tabular}

Kronbahov $\alpha$ koeficijent za upitnik u celini iznosi .627, što predstavlja pouzdanost ispod arbitrarne granice. Ipak, imajući u vidu da upitnik sadrži samo 10 tvrdnji, može se zaključiti da ima prihvatljivu pouzdanost (svaka vrednost Kronbahovog $\alpha$ koeficijenta iznad .60 je prihvatljiva /Bishop, 2003/). 


\section{Rezultati istraživanja}

Tabela 3. Izraženost merenih tvrdnji za celokupan uzorak

\section{R.br. Tvrdnja}

AS SD

1. Upoznat sam sa rezultatima spoljašnjeg vrednovanja škole $\quad 5.00 \quad .00$

2. Smatram da je procena kvaliteta rada škole u skladu sa

$4.75 \quad .46$ stvarnim stanjem/situacijom u školi

3. Uključen sam u donošenje strategije/akcionog plana za

$4.75 \quad .46$ otklanjanje slabih strana

4. Jasno mi je šta treba da menjam u sopstvenom radu $4.63 \quad .52$

5. Korigovani su individualni planovi nastavnika $3.25 \quad 1.49$

6. Korigovani su planovi koji pokrivaju rad škole u celini

3.131 .89
(Godišnji plan rada, Školski program)

7. Izmenjen je Školski razvojni plan $3.75 \quad 1.17$

8. Došlo je do izmena u procesu samovrednovanja $4.13 \quad .84$

9. Izmenjen je protokol o poseti i posmatranju časova $4.00 \quad 1.60$

10. Unete su promene u polju informisanja učenika o 3.881 .36 postignućima u učenju

Tabela 4. Izraženost tvrdnje: Upoznat sam sa rezultatima spoljašnjeg vrednovanja škole u zavisnosti od tipa škole u kojoj stručni saradnici rade

\begin{tabular}{lcccc}
\hline $\begin{array}{l}\text { Upoznat sam sa rezultatima spoljašnjeg } \\
\text { vrednovanja škole }\end{array}$ & MIN & MAX & AS & SD \\
\hline Osnovna škola - grad & 5 & 5 & 5.00 & .00 \\
\hline Osnovna škola - selo & 5 & 5 & 5.00 & .00 \\
\hline Srednja stručna škola & 5 & 5 & 5.00 & .00 \\
\hline Gimnazija & 5 & 5 & 5.00 & .00 \\
\hline
\end{tabular}

Iz obrađenih rezultata može se zaključiti da su svi ispitanici upoznati sa rezultatima spoljašnjeg vrednovanja rada škole - bez obzira od tipa škole u kojoj rade. 
Tabela 5. Izraženost tvrdnje: Smatram da je procena kvaliteta rada škole u skladu sa stvarnim stanjem/situacijom u školi u zavisnosti od tipa škole

\begin{tabular}{lllll}
\hline $\begin{array}{l}\text { Smatram da je procena kvaliteta rada škole } \\
\text { u skladu sa stvarnim stanjem/situacijom u } \\
\text { školi }\end{array}$ & MIN & MAX & AS & SD \\
\hline Osnovna škola - grad & 5 & 5 & 5.00 & .00 \\
\hline Osnovna škola - selo & 4 & 5 & 4.50 & .71 \\
\hline Srednja stručna škola & 5 & 5 & 5.00 & .00 \\
\hline Gimnazija & 4 & 5 & 4.50 & .71 \\
\hline
\end{tabular}

Analiza odgovora na navedene tvrdnje ukazuje na manja odstupanja; pedagozi osnovne škole iz gradske sredine i srednje stručne škole saglasni su da je procena kvaliteta rada škole u skladu sa stvarnom situacijom u školi i u potpunosti tačna, dok se mišljenja pedagoga iz seoskih osnovnih škola i gimnazija podeljena između najviše ocenjenih tvrdnji (u potpunosti i često se slažem). Rezultati ukazuju na poznavanje procesa spoljašnjeg vrednovanja i ulogu pedagoga u procesu samovrednovanja škola.

Tabela 6. Izraženost tvrdnje: Uključen sam u donošenje strategije / akcionog plana za otklanjanje slabih strana u zavisnosti od tipa škole u kojoj stručni saradnici rade

\begin{tabular}{lcccc}
\hline $\begin{array}{l}\text { Uključen sam u donošenje strategije / } \\
\text { akcionog plana za otklanjanje slabih strana }\end{array}$ & MIN & MAX & AS & SD \\
\hline Osnovna škola - grad & 5 & 5 & 5.00 & .00 \\
\hline Osnovna škola - selo & 4 & 5 & 4.50 & .71 \\
\hline Srednja stručna škola & 5 & 5 & 5.00 & .00 \\
\hline Gimnazija & 4 & 5 & 4.50 & .71 \\
\hline
\end{tabular}

Iskazane tvrdnje ukazuju da su pedagozi ispitane gradske osnovne i srednje stručne škole u celini uključeni u donošenje strategije i izradu akcionog plana za otklanjanje slabih strana škole utvrđenih spoljašnjim vrednovanjem, ali i da su pedagozi seoske škole i gimnazije delimično uljučeni. Razlog slabijeg uključivanja pedagoga seoske škole je nepotpuna 
norma koju u jednoj školi ostvaruju i njihova vremenska podeljenost. Razlog slabijeg uključivanja pedagoga gimnazije konstatovana je ocenom koju je škola dobila u procesu spoljašnjeg vrednovanja (nedovoljna), I rezultat je niza utvrđenih slabosti.

Tabela 7. Izraženost tvrdnje: Jasno mi je šta treba da menjam u sopstvenom radu u zavisnosti od tipa škole u kojoj stručni saradnici rade Jasno mi je šta treba da menjam u MIN MAX AS SD sopstvenom radu

\begin{tabular}{lllll}
\hline Osnovna škola - grad & 4 & 5 & 4.50 & .71 \\
\hline Osnovna škola - selo & 4 & 5 & 4.50 & .71 \\
\hline Srednja stručna škola & 4 & 5 & 4.50 & .71 \\
\hline Gimnazija & 5 & 5 & 5.00 & .00 \\
\hline
\end{tabular}

Pegagozi škola iz uzorka uključeni su u osmišljavanje, donošenje i realizaciju akcionih planova za prevazilaženje slabih strana u funkcionisanju škola, i u njihovim odgovorima uočava se da su dobro upoznati sa neostvarenim i delimično ostvarenim standardima nakon spoljašnjeg vrednovanja; posebno se to vidi na primeru gimnazije koja je imala slabu ocenu i većinu neostvarenih standarda kvaliteta.

Tabela 8. Izraženost tvrdnje: Korigovani su individualni planovi nastavnika u zavisnosti od tipa škole

\begin{tabular}{lcccc}
\hline $\begin{array}{l}\text { Korigovani su individualni planovi } \\
\text { nastavnika }\end{array}$ & MIN & MAX & AS & SD \\
\hline Osnovna škola - grad & 4 & 4 & 4.00 & .00 \\
\hline Osnovna škola - selo & 4 & 4 & 4.00 & .00 \\
\hline Srednja stručna škola & 1 & 5 & 3.00 & 2.83 \\
\hline Gimnazija & 1 & 3 & 2.00 & 1.41 \\
\hline
\end{tabular}

Jedna od slabih strana škole uočena prilikom spoljašnjeg vrednovanja je planiranje i pripremanje nastavnika za rad. Odgovori pedagoga ukazuju na spremnost nastavnika za promene na polju planiranja i pripremanja za rad, najviše u osnovnim školama a u znatno manjoj meri 
kod nastavnika zaposlenih u srednjim školama, posebno u gimnaziji, što se može povezati sa činjenicom da su nastavnici srednjih škola u manjoj meri bili uključeni u procese reformi.

Tabela 9. Izraženost tvrdnje: Korigovani su planovi koji pokrivaju rad škole u celini (Godišnji plan rada, Školski program) u zavisnosti od tipa škole

\begin{tabular}{lcccc}
\hline $\begin{array}{l}\text { Korigovani su planovi koji pokrivaju rad } \\
\text { škole u celini }\end{array}$ & MIN & MAX & AS & SD \\
\hline Osnovna škola - grad & 1 & 5 & 3.00 & 2.83 \\
\hline Osnovna škola - selo & 4 & 5 & 4.50 & .71 \\
\hline Srednja stručna škola & 1 & 5 & 3.00 & 2.83 \\
\hline Gimnazija & 1 & 3 & 2.00 & 1.41 \\
\hline
\end{tabular}

Različitost odgovora ukazuje na nespremnost timova u školi za promene na polju sređivanja ključne pedagoške dokumentacije škole. To znatno varira u zavisnosti od vrste škole, kao i njenog lokaliteta.

Tabela 10. Izraženost tvrdnje: Izmenjen je Školski razvojni plan u zavisnosti od tipa škole

\begin{tabular}{lllll}
\hline Izmenjen je Školski razvojni plan & MIN & MAX & AS & SD \\
\hline Osnovna škola - grad & 2 & 4 & 3.00 & 1.41 \\
\hline Osnovna škola - selo & 3 & 3 & 3.00 & .00 \\
\hline Srednja stručna škola & 5 & 5 & 5.00 & .00 \\
\hline Gimnazija & 3 & 5 & 4.00 & 1.41 \\
\hline
\end{tabular}

Izraženost tvrdnje o promenama Školskog razvojnog plana, takođe, ukazuje na različitost škola u pogledu shvatanja značaja ovog dokumenta. Izmenama ovog dokumenta značaj u potpunosti pridaju ispitani pedagozi srednje stručne škole, koja je spoljašnjim vrednovanjem dobila najvišu ocenu. 
Tabela 11. Izraženost tvrdnje Došlo je do izmena u procesu samovrednovanja u zavisnosti od tipa škole.

\begin{tabular}{lcccc}
\hline $\begin{array}{l}\text { Došlo je do izmena u procesu } \\
\text { samovrednovanja }\end{array}$ & MIN & MAX & AS & SD \\
\hline Osnovna škola - grad & 3 & 4 & 3.50 & .71 \\
\hline Osnovna škola - selo & 3 & 5 & 4.00 & 1.41 \\
\hline Srednja stručna škola & 5 & 5 & 5.00 & .00 \\
\hline Gimnazija & 4 & 4 & 4.00 & .00
\end{tabular}

Podaci iz Tabele 11 ukazuju na to da je do najvećih izmena u procesu samovrednovanja došlo u srednjim školama, što je u vezi sa ocenama dobijenim spoljašnjim vrednovanjem (Gimnazija je dobila najslabiju ocenu a suština promena vidi se u promenama vrednovanja sopstvenih snaga, dok je stručna škola spoljašnjim vrednovanjem dobila najvišu ocenu i nastojala da zadrži nivo kvaliteta stalnim vrednovanjem). Podaci osnovnih škola pokazuju da je planiranje izvršeno na dugoročnom planu, ali i nespremnost za menjanje tih planova pre njihovog isteka.

Tabela 12. Izraženost tvrdnje: Izmenjen je protokol o poseti $\boldsymbol{i}$ posmatranju časova u zavisnosti od tipa škole

Izmenjen je protokol o poseti i posmatranju MIN MAX AS SD časova

\begin{tabular}{lllll}
\hline Osnovna škola - grad & 5 & 5 & 5.00 & .00 \\
\hline Osnovna škola - selo & 4 & 5 & 4.50 & .71 \\
\hline Srednja stručna škola & 1 & 5 & 3.00 & 2.83 \\
\hline Gimnazija & 2 & 5 & 3.50 & 2.12 \\
\hline
\end{tabular}

Rezultati iz Tabele 12 potvrđuju da su u velikoj meri izmenjeni protokoli o poseti i posmatranju časova. Na tu činjenicu uticalo je spoljašnje vrednovanje i pedagozi u većini slučajeva koriste protokol o poseti i posmatranju preuzet od Ministarstva prosvete, nauke i tehnološkog razvoja kojim se preciznije mere standardi kvaliteta rada. Treba napomenuti da su slabije ocenjene trvrdnje od strane pedagoga srednje stručne škole jer su oni u svom radu do sada koristili identične protokole. 
Tabela 13. Izraženost tvrdnje: Unete su promene u polju informisanja učenika o postignućima u učenju u zavisnosti od tipa škole

Unete su promene u polju informisanja MIN MAX AS SD učenika o postignućima u učenju

\begin{tabular}{lllll}
\hline Osnovna škola - grad & 4 & 5 & 4.50 & .71 \\
\hline Osnovna škola - selo & 4 & 4 & 4.00 & .00 \\
\hline Srednja stručna škola & 1 & 5 & 3.00 & 2.83 \\
\hline Gimnazija & 3 & 5 & 4.00 & 1.41 \\
\hline
\end{tabular}

Tabela 13 pokazuje da je informisanost učenika o postignućima u učenju na visokom nivu a da nema značajnih razlika između različitih tipova škole; kod srednjih škola je spoljašnjim vrednovanjem utvrđeno da je informisanost učenika o postignućima u učenju na visokom nivou i iz tih razloga nije bilo većih promena.

\section{Značajnost razlike u izraženosti rezultata}

U Tabeli 16 prikazana je razlika u izraženosti merenih tvrdnji u zavisnosti od tipa škole u kojoj stručni saradnici rade. Nisu dobijene statistički značajne razlike ni za jednu od merenih tvrdnji. Za Tvrdnju br. 1. Upoznat sam sa rezultatima spoljašnjeg vrednovanja škole - svi ispitanici su odgovorili uvek isto (5); dakle, nema razlika (ovo se smatra normalnim, jer prilikom davanja povratne informacije o izvršenom spoljašnjem vrednovanju škole, obavezno je da prisustvuju i stručni saradnici). 
Tabela 16. Značajnost razlika u izraženosti merenih tvrdnji u zavisnosti od tipa škole u kojoj stručni saradnici rade

R.br. Tvrdnja $\quad$ F p

1. Upoznat sam sa rezultatima spoljašnjeg vrednovanja škole

2. Smatram da je procena kvaliteta rada škole u skladu sa $\quad \begin{array}{lll}667 & .615\end{array}$ stvarnim stanjem/situacijom u školi

3. Uključen sam u donošenje strategije/akcionog plana za $\quad .667 \quad .615$ otklanjanje slabih strana

4. Jasno mi je šta treba da menjam u sopstvenom radu $\quad \begin{array}{lll}.333 & .803\end{array}$

5. Korigovani su individualni planovi nastavnika $\quad \begin{array}{lll}.733 & .584\end{array}$

6. Korigovani su planovi koji pokrivaju rad škole u celini $\quad \begin{array}{lll}459 & .726\end{array}$ (Godišnji plan rada, Školski program)

7. Izmenjen je Školski razvojni plan $\quad \begin{array}{lll}1.833 & .281\end{array}$

8. Došlo je do izmena u procesu samovrednovanja $\quad 1.267 \quad 398$

9. Izmenjen je protokol o poseti i posmatranju časova $\quad \begin{array}{lll}.513 & .695\end{array}$

10. Unete su promene na polju informisanja učenika o $\quad \begin{array}{lll}.302 & .824\end{array}$ postignućima u učenju $d f=8$;

\section{Značajnost razlika u izraženosti merenih tvrdnji u zavisnosti od pola stručnih saradnika}

Značajnost razlika u izraženosti merenih tvrdnji u odnosu na pol stručnih saradnika ne prikazuje se jer su svi ispitanici - stručni saradnici ženskog pola. U Tabeli 18 prikazana je značajnost razlika u izraženosti merenih tvrdnji kod stručnih saradnika u zavisnosti od okruga (mesta). Nisu dobijene statistički značajne razlike ni za jednu od merenih tvrdnji. Tvrdnja 10 - Unete su promene u polju informisanja učenika o postignućima u učenju - nije statistički značajna $(\mathrm{p}=0.058)$, ali je na granici nivoa značajnosti $\mathrm{p}<0,05$. Isto tako, za Tvrdnju 1 - Upoznat sam sa rezultatima spoljašnjeg vrednovanja škole - svi ispitanici su odgovorili jednako (iz navedenih razloga). 
Tabela 18. Značajnost razlika u izraženosti merenih tvrdnji u zavisnosti od mesta (okruga)

R.br. Tvrdnja t $\quad$ p

1. Upoznat sam sa rezultatima spoljašnjeg vrednovanja škole

2. Smatram da je procena kvaliteta rada škole u skladu sa $\quad .000 \quad 1.000$ stvarnim stanjem/situacijom u školi

3. Uključen sam u donošenje strategije/akcionog plana za $\quad .000 \quad 1.000$ otklanjanje slabih strana

4. Jasno mi je šta treba da menjam u sopstvenom radu $\quad \begin{array}{lll}6 & .55 & .537\end{array}$

5. Korigovani su individualni planovi nastavnika $\quad-.447 \quad .670$

$\begin{array}{llll}\text { 6. Korigovani su planovi koji pokrivaju rad škole u celini } & -.928 & .389\end{array}$ (Godišnji plan rada, Školski program)

7. Izmenjen je Školski razvojni plan $\quad-1.265 \quad .253$

\begin{tabular}{lllll}
\hline 8. Došlo je do izmena u procesu samovrednovanja & .397 & .705
\end{tabular}

9. Izmenjen je protokol o poseti i posmatranju časova $\quad \begin{array}{llll}-1.414 & .207\end{array}$

10. Unete su promene na polju informisanja učenika o $\quad-2.333 \quad .058$ postignućima u učenju $d f=8$

\section{Zaključak}

$\mathrm{Na}$ osnovu analize dobijenih odgovora i obradom podataka, potvrđena je opšta hipoteza da učesnici obrazovno-vaspitnog procesa (stručni saradnici - pedagozi) procenjuju spoljašnje vrednovanje kao važan činilac. Posebna hipoteza da na stavove pedagoga kao učesnika obrazovno-vaspitnog procesa ne utiču značajno razlike u lokalitetu škole i polu ispitanika - potvrđene su, a nije potvrđena posebna hipoteza da na njihove stavove značajno ne utiču razlike u vrsti škole.

Odgovori pedagoga pokazali su da su upoznati sa rezultatima spoljašnjeg vrednovanja škole i da u velikoj meri smatraju da je procena kvaliteta rada škole od strane evaluatora u skladu sa stvarnim stanjem u školi. Oni procenjuju važnim doprinos spoljašnjeg vrednovanja škole i smatraju da će promene koje je iniciralo spoljašnje vrednovanje dovesti 
do poboljšanja kvaliteta rada prilikom narednog spoljašnjeg vrednovanja. Takođe su konstatovali da su u manjoj meri pokrenute nastavne i vannastavne aktivnosti i međusobna saradnja u školi, ali i da je nakon izvršenog spoljašnjeg vrednovanja organizovaniji rad školskih tela u koje su uključeni. Jasno im je šta bi trebalo da menjaju u sopstvenom radu, u većoj meri imaju odgovarajuću pomoć i podršku za unapređivanje kvaliteta svog rada, smatraju da postojeća struktura u školi omogućava pozitivne promene, kao i da imaju odgovarajuće uslove za unošenje promena u svoj rad.

\section{AN ANALYSIS OF THE PEDAGOGOUES' ATTITUDE TOWARDS AN EXTERNAL EVALUATION}

\section{SUMMARY}

Abstract: The aim of the research was to examine how expert associates (pedagogues) estimated the contribution of the external evaluation, and whether they realized its importance for the improvement of work, and both personal and professional development. Data collection was conducted by the interviewing technique, and the questionnaire and evaluation scales were used as an instrument. The sample consisted of eight expert associates from eight schools which have undergone external evaluation. The results indicated that the expert associates evaluated as important a contribution to the external evaluation of the school work. In addition, the results emphasized the differences in these perceptions, creating a possibility for continuation of the sample research of such teachers' attitudes.

Key words: expert associates, attitudes, external evaluation.

\section{Literatura}

Andevski, M. i Dunđerski, S. (2006). Obrazovni standardi i menadžment kvaliteta u školi. Godišnjak Filozofskog fakulteta u Novom Sadu, Novi Sad, (31), 667-678.

Izveštaji Tima za spoljašnje vrednovanje za 2014. godinu, po Rešenju ministra prosvete, nauke i tehnološkog razvoja br. 614-02-101/1415/4 od 29. 1. 2014. 
Obrazac za sveukupnu procenu ostvarenosti standarda kvaliteta rada škola (2012). Zavod za vrednovanje kvaliteta obrazovanja i vaspitanja.

Pravilnik o vrednovanju kvaliteta rada ustanove (2012). Službeni glasnik RS, br. 9/12.

Standardi kompetencija za profesiju nastavnika i njihovog profesionalnog razvoja (2011). Zavod za unapređivanje obrazovanja i vaspitanja. Beograd: ZUOV.

Standardi kvaliteta rada obrazovno-vaspitnih ustanova (2010). Zavod za vrednovanje kvaliteta obrazovanja i vaspitanja. Beograd: ZUOV.

Standard znanja, veština $i$ vrednosnih stavova (kompetencije) za profesiju nastavnika, Zavod za unapređivanje obrazovanja i vaspitanja, nacrt. Zakon o osnovama sistema obrazovanja $i$ vaspitanja (2013). Službeni glasnik RS, br. 72/09, 52/11, 55/13. 